\title{
Economic Value Added and Stock Market Development in Egypt
}

\author{
Mansoor Maitah ${ }^{1}$, Nayif Saleem ${ }^{1}$, Karel Malec ${ }^{1}$, Mohammed Boubaker ${ }^{2} \&$ Shreen Gouda $^{1}$ \\ ${ }^{1}$ Department of Economics, Faculty of Economics and Management, Czech University of Life Sciences Prague, \\ Czech Republic \\ ${ }^{2}$ Department of Management, Faculty of Economics and Management, Czech University of Life Sciences \\ Prague, Czech Republic \\ Correspondence: Mansoor Maitah, Faculty of Economics and Management, Czech University of Life Sciences \\ Prague, Kamycka 129, Prague 6 16921, Czech Republic. E-mail: Maitah@pef.czu.cz
}

Received: September 13, 2014 Accepted: November 5, 2014 Online Published: December 30, 2014

doi:10.5539/ass.v11n3p126 URL: http://dx.doi.org/10.5539/ass.v11n3p126

\begin{abstract}
This paper examines the relationship between economic value added and stock prices, and analyzes the benefit of the use of Economic Value Added (EVA) in the creating process of investment policies that can be helpful to get extraordinary returns. The research tests a private data collection of companies traded at Egyptian stock market. To achieve the overall objective the paper is divided as follows: the first part of the study is an analysis of the fields which study the relationship between the scale of the EVA, stock price and dividends. Section two of the paper deals with the literature review while section three presents the study hypotheses and section four deals with the methodology of the study. The last part includes the summary of the research and its results.
\end{abstract}

Keywords: value added, stock return, investment, interest, assets

\section{Introduction}

The tool of "economic value added" quantifies of efficient performance is one of the most accepted economic concepts to express the residual income after deducting the cost of capital invested in the company. The concept of residual income can generate the profit for stakeholders. So the company management should use the available resources in such conducive way to get a return of invested capital that is greater than the capital cost, whether (owned or borrowed). In contrast, the concept of accounting profit is based on the difference of the net profit and the cost for interest (for borrowed money). The residual income concept is represented as the value of net operating profit after tax after operation minus the value of the average cost of capital invested on the company. The residual income can be expressed as follows:

$$
\mathrm{RI}_{\mathrm{t}}=\mathrm{NOPAT}_{\mathrm{t}}-\text { Cost of Capital } t
$$

Where:

$\mathrm{RI}_{\mathrm{t}}$ Is the residual income on the time $t$.

NOPAT $_{t}$ for net operation income after tax and without deducting interest on the same time (t)

Cost of the Capital $t$ Is the cost of the capital calculated as

Capital of Capital $_{t}=\mathrm{WACC} \times$ Capital

where:

WACC Is the weighted average cost of capital (owned or borrowed)

Capital Is the capital invested whiter (owned or borrowed)

According to Stern Stewart \& Co, the EVA can be calculated as

$$
\text { EVA }=\text { Adjusted NOPAT }- \text { Adjusted Cost of Capital }
$$

Where:

EVA Is the Economic Value Added.

Adjusted NOPAT as adjusted net operation income after tax and without deducting the interest. 
The EVA takes a positive value if the adjusted net operating profit after tax is greater than the value of the adjusted cost of invested capital, in the contrast EVA takes a negative value if the value of the adjusted net operating profit is less than the adjusted cost of the invested capital. Stern Stewart \& Co has undertaken several adjustments to the net operating profit accounting to prevent the impact of accounting policies on the profit. The company introduced adjustments to the concept of the invested capital, which is suitable to quantify the average cost of capital. The aim of these adjustments is calculate the net economic profit, not the accounting profit. So the exclusion of certain accounting adjustments, which do not involve cash flows and the capital adjustment, to reflect the assets value invested on the company along with excluding the effect of accounting policies gives the opportunity for comparison between either the results of the performance of different companies or different sections within the same company. It also helps to decrease the possibilities for management to use accounting policies designed to control profitability that are saluting the removal of the impact of these policies. (Stern Stewart \& Co) has pointed out that these amendments are fundamental for getting the net operating profit accounting on many of the values, which do not reflect the cash flows, and are influenced by using different accounting policies.

The net EVA has impact on the market value of the company. It could be stated that increasing EVA for any company causes its growing market value. Stern Stewart also provided another measure for the company's performance: the market value added (MVA). This is calculated as:

$$
\text { MVA }=\text { MV of the firm }- \text { Capital }
$$

Where:

MVA Is the Firm Market Value Added

MV Is the Firm Market Value

Capital Is the capital invested on the firm after making the adjustment suggested by Stern Stewart \&Co

There could be observed the positive relationship between the MVA of the company and its net EVA, Therefore, the MVA reflect the net present values of the EVA, which it is expected to achieve in the future, For example, in the case of a predicted steady economy, the value added of the company in the future (with the absence of growth), the MVA, can be calculated as follows (Peterson, 1997):

$$
\mathrm{MVA}=\frac{E V A}{K}
$$

Where:

$\mathrm{K}$ Is the Require Rate of Return which reflects the cost of the capital

Also, the Stern Stewart Company has undertaken a great marketing campaign for the concept of EVA measurement and the various adjustments that should be done on the net accounting profit in addition to the brand (EVA), The results of this campaign have allowed the company to expand to a larger number of customers, with 300 clients representing facilities and, great business, with many companies around the world. A set of statements for attracting customers (eye -catching statements), were also included in the advertisements for the company. EVA e.g. measure is the key to creating wealth for shareholders, so the true measure of a company's performance is the EVA, not the earnings per share or return on investment or return on equity property. Stewart (1991-1994) said proponents of the measure that any change in the value of the company was due to a change its EVA (Tully, 1993-1994).

In addition, to the claim he can use the EVA changes in the classification of the company's value and its stock returns better than classic accounting standards (Stewart, 1994). The spread of the concept of EVA and a high number of customers (Stern Stewart \&Co) to the emergence of many performance metrics of economic competition marketed by different companies, has led the competition to be noted in the newspapers and financial magazines. These called it the war scales between different companies, for example, the scale of Cash Flows Return on Investment rate (CFROI), which are marketed by (HOLT Value Association), the Total Business Return (TBR), which are marketed by (Boston Consulting Group), Shareholders Value Added (SVA) the Company (LEK /Aclar),discounted economic profits for Marakon Associates, and finally Economic Value management KPMG.

The theatrical claims have led the importance of standard EVA in the creation of shareholders' wealth, and the role of EVA in the interpretation of stocks return and changes in the market value of the company, to spread the concept to many publications and books on performance measures of internal and external accounting. There have been calls to disclose the measure of the value added of the business instead of companies disclosing 
earnings per share of the profit, and the results of the business and stock performance reports in newspapers and financial magazines (Zarowin, 1995). In spite of mentioned above, there is a logical explanation for the theoretical relationship between the EVA and shares prices and revenues, but where is also criticism on this scale including:

The measurement of EVA reliable on the value is reflected in the historical statements accounts after making various adjustments. It presents the historical events but does not reflect the expectation of the EVA in the future. Therefore, using it to determine the company value and to forecast the expected stock price is not proper, because the future price is connected with future, not past, circumstances. Regardless of the publicity for the EVA, it may convince many researchers to believe that it represents a new theory for all the problems of other measurements. However, does not provide any development of the known concepts for profit economic.

The EVA tool is not practical model that can be helpful for the stocks rating and determining the company value.

To calculation of EVA needs adjustment on the numbers on the financial statements'. These adjustments need a set of data, which appears on the series of financial statements In contrast to residual income and can be calculated directly. According to many studies (Biddle et al., 1997-1999), there are no significant differences and effects between the value of each of the residual income derived from Equation (1) and the EVA derived from Equation (2). Therefore, there is no theatrical value to these adjustments, which were proposed by (Stern Stewart $\& \mathrm{Co}$ ) on the accounting numbers to measure the EVA.

In addition to the criticisms on the theory to measure the validity of the use of EVA to interpret the changes in stock price and revenues, many empirical studies show the field of claims of the supporters of the theoretical of measure of EVA. (Biddle et al., 1997, 1999; Velez - Pareja, 2001; Peixoto, 2002)

\section{Literature Review}

According to the theoretical relationship between the EVA and stock prices and revenues, the high EVA generated by the facility increases its value, and thus is reflected in the high prices of the shares of these established companies. As the case of the validity of these allegations, the theoretical composition of investment portfolios contains the shares of enterprises with high EVA, so we must achieve extraordinary returns compared to all the average market returns and returns on portfolios that contain the shares of enterprises with low EVA.

There are many studies focused on testing causality between prices and earnings indicators of EVA and the remaining income and accounting indicators recognized as dependent variables. One of the leading studies in this area has targeted the testing the relationship between the EVA of all dividends and the value of the entity. The study tested whether the data value-added and value components of this help explain the stock returns and changes in the value of the companies more data from the accounting profits or not. According to the outputs of the research can be said that the profit accounting helped in interpreting the returns stocks better than all the data residual income and the EVA, also the results indicate that profits contribute to the interpretation of accounting earnings and the stock value of the business greater than other economic scales, so this refers to the futility amendments proposed by Stern Stewart \& Co.

Biddle et al. (1997) tested the same pre-existing relationships in the period following the appearance of an article (Tully 1993), which pointed out that the use of standard value-added economic is the real key to creating the wealth of shareholders, and showed that they have had an high impact on the popularity of the concept of EVA measure. Research was focused on causality by using the 606 view results and was shown no support to the theory that the allegations refer to the superiority measure that the EVA to the Metrology accounting in the interpretation of changes in stock prices. O'Byrne (1996) tested the relationship between stock returns and between both the EVA and net operating profit after tax accounting. Based on the studies the accounting profits contributed to the interpretation of the stock return to a lesser extent than the EVA, but that the difference between the scales is not a factor (manor reached $33 \%$ of the relationship between stock return and EVA). The study concluded that these scales indicate raising the contribution of standard EVA in the interpretation of stock returns for traditional accounting scales. This study was criticized because modifications were carried out when testing the scale of the economic value and he did not make the same adjustments for an analysis of the relationship between returns shares and profit accounting.

Bernstein and Pigler (1997) tested the possibility of using data with the EVA in the composition of investment portfolios that seek normal returns, and that through the formation of investment portfolios based on the data, the EVA of the shares and trade policies is based on buying high-value stocks and selling stocks with a low EVA. The study pointed out that if we assume the theoretical validity of the claim that companies that achieve high EVA claim to raise the wealth of shareholders, the composition of investment portfolios containing companies 
that achieve high EVA is expected to get high rate of return compared with the average returns in the stock market. In addition, the average yield that is possible to be achieved by using the investment policies is based on well known accounting indicators. The study of the composition of portfolios among the registered businesses in the New York market was covered by the S \& P 500 index for the period from 1987 to 1997. The study's results showed that contrary to allegations, the use of theoretical measures for the EVA as a basis for the selection of business premises within the portfolio did not make any unusual return.

Based on the results of previous studies and the business registered in the stock markets, it is clear that much of the scientific evidence that indicates a lack of health (Almzagm theory) advocating the superiority of the measure of EVA in explaining the behavior of prices and returns of stocks on the indicators of accounting practices. As indicated in the results of these studies, amendments proposed by the Stern Stewart \& Co. are not feasible. On the accounting figures to reach the EVA, saluting contributions to residual income calculated directly from the accounting figures published after the deduction of the cost of capital, expresses the changes in stock prices and returns more than the contribution of the EVA.

\section{Study Hypotheses}

To achieve the overall objective of the study and based on the balance of the accounting research in the field, we test the relationship between stock price and earnings and the EVA. In this paper, we will test two assumptions. The first one will measure the relationship between the returns on shares of businesses and the EVA generated by this topic installations, and aims to test the validity of the assumption that the companies with high EVA have higher dividends. In other words, the shares with high EVA included to the portfolio represents higher probability to get higher rate of return than it is average at the stock market. The hypothesis can be formulated as follows:

The first hypothesis:

Using the EVA to design the investment policies leads to increasing normal returns on investment compare with market return.

The second hypothesis:

The use EVA investment policies achieves higher average returns than the average returns achieved by the investment strategy using the most common accounting indicators.

\subsection{Data and Methodology}

Research sample was selected from a group of registered enterprises in the stock market in Egypt. The term of study included three years in the period from the beginning of 2005 to 2007. The study sample included over 40 businesses (23), representing the most active companies according to the official bulletin of the Stock Exchange in Cairo and Alexandria (17). And we can test the major hypotheses for research, and achieve the overall objective using the availability of the following data:

1. Annual financial statements for the year 2005 (to use the data for net accounting profit and the book value of property rights, and to calculate the rate of return on the property rights and the value of long-term loans and costs).

2. The annual dividends to shareholders and the date of distribution.

3. Stock prices daily enterprise group was under study since the beginning of 2005 and 2007 to account for dividends accrued daily and during the period.

4. The daily value for the index to calculate the average market return in the same period of the study.

The following conditions apply to determine the final sample to search:

- Use data from the financial statements of accounting at the beginning of the study period.

- Availability of data on daily closing prices for the businesses under study.

- Use the data from Egypt stock market index, (CASE30).

Table 1. Descriptive analysis of companies under study by the market value of the business (value in million EGP)

\begin{tabular}{cccccccccc}
\hline $\begin{array}{c}\text { Number } \\
\text { of views }\end{array}$ & mean & intermediate & $\begin{array}{c}\text { Trimmed } \\
\text { mean }\end{array}$ & $\begin{array}{c}\text { Standard } \\
\text { error }\end{array}$ & $\begin{array}{c}\text { Standard } \\
\text { deviation }\end{array}$ & $\begin{array}{c}\text { Low } \\
\text { value }\end{array}$ & $\begin{array}{c}\text { High } \\
\text { value }\end{array}$ & $\begin{array}{c}\text { First } \\
\text { quarter }\end{array}$ & $\begin{array}{c}\text { Third } \\
\text { quarter }\end{array}$ \\
\hline 40 & 1588 & 505 & 1202 & 404 & 2829 & 8.8 & 16590 & 162 & 1689 \\
\hline
\end{tabular}


The application of the conditions precedent to the exclusion of three companies listed among the companies most active in 2007, but that the date of registration of these companies in the stock market is a relatively recent date. In addition, that there is no series of integrated data on the prices of traded shares during the study period. So, the final sample for the study included 28 companies registered in the stock market, giving a total market value of 31.78 billion pounds. Table 1 describes the companies by the market value of the business.

The trimmed mean can be calculated after deducting the highest and lowest $5 \%$ from all views.

There were used following setps to test the causality between EVA and stock return and the first assumption is based on adoption of EVA for private sector to achieve higher returns in comparison with market average:

1. Account the EVA in each stock sample under study and for that over the years of study. Due to the lack of disclosure of the EVA, according to the adjustments proposed by Stern Stewart that rely on the scale of economic profits (residual income), which can be observed from published accounting lists, after the authorities agreed the average cost of capital (using equation 1), and has been calculated on the basis of rate of return without risk, in addition to a premium for risk.

2. Ordering the companies downward according to the earnings per share of the EVA in the beginning of the period. The composition of investment portfolio consists of set of companies that generate the highest EVA per share (the top twenty percents) and the theoretical claim supposed that the investments provide porfit to the shareholders, and thereby achieve a high rate of return compared with the average market return during the same period.

The rate is calculated to achieve the expected return on the property rights as follows:

$(\mathrm{RRR}=\mathrm{RFR}+$ Risk premium)

Where:

RRR Is the required rate of return achieved on the property rights

RFR Is the free rate of return without risk has been used rate of return on treasury bonds at the beginning of the study period as a basis for the rate of return risk - free.

Risk Premium Is a premium for risk, despite the difference of the premium, according to industry type and size of the facility replaces the analysis, the assumption has been deafening silence as well as one for all the companies of $4 \%$.

3- Calculating the daily returns for all stocks on the sample of the study on basis over the study period (from 01.01.2005 until 31.12.2007), as follows

$$
R_{i t}=\left(P_{i t}-P_{i t-1}\right)+D_{i t}
$$

Where:

$R_{i t}$ is the share return on the any day (i)

$P_{i t}$ is current share price on the end of any day $(\mathrm{t})$

$P_{i t-1}$ is the share price on the previous day ( $\left.\mathrm{t}-1\right)$

$D_{i t}$ the profit dividend

4- Calculate the daily return of the stock market on a daily basis over the study period (from the first of January 2005 until thirty-first of December 2007) as follows:

$$
\mathrm{R}_{\mathrm{mt}}=\frac{\left(\mathrm{M}_{\mathrm{it}}-\mathrm{M}_{\mathrm{it}-1}\right)}{\mathrm{M}_{\mathrm{it}-1}}
$$

Where:

$R_{m t}$ The market return on the day ( $\mathrm{t}$ ) and using market index (CASE30) to calculate it

$M_{i t}$ The index value on the end of day (t)

$M_{i t-1}$ The market index value in the perfuse day ( $\mathrm{t}-1$

5- Collecting the daily returns on a monthly basis per share of the sample and the market index as follows:

$$
C R_{i t}=\sum_{t=1}^{t=k} R_{i t}
$$

Where:

$C R_{\text {it }}$ Sum of share return on the day ( $\left.\mathrm{t}\right)$

$\mathrm{K}$ The total time of study (42 months)

$R_{i t}$ The share (i) return on the day (t) 
So we estimate the accumulated return of the market index during the study period using data market return instead of the market return.

6 - Compare portfolio returns on stocks with the highest EVA. Average market portfolio returns and, the ability to compare the extent of this portfolio to determine the sectors (segments) in the market securities portfolio, suitable to get higher profit compared to market return.

The test of the second assumption is based on the comparison the returns generated by the investors'strategy including the scale of the EVA, with the revenues of investment policies based on indicators of accounting practices, using earning multiplier indicator, indicating the causality between the worth of shares returns for share of the profit. This is calculated as follows:

$$
\frac{P}{\mathbf{E}}=\frac{\mathbf{P}_{\mathbf{t}}}{\mathbf{E P S}}
$$

\section{$P / E$ Earnings Multiplier}

$P_{t}$ Share price on the time $(\mathrm{t})$

The earning multiplier has been calculated for all the shares of enterprises subject to study at the beginning of the study period (1January2005) and the investment policy designed based on the data of earning multiplier by following these steps:

1 - Order the companies in our sample in accordance to the profit multiplier in the beginning of the period. The portfolio consists of the enterprises having minimum profit multiplier. The investment in these companies leads to achieving high investment returns compared with an average market and the rest of the firms with a high value of earning multiplier.

2- Measuring the stock return for all components of the sample under study on a daily basis over the period of study (the first of January 2005 to the thirty-first of December 2007) according to the Equation (5) during the study period, using the equation (7).

3- Compare the stocks portfolio revenue with the lowest earnings multiplier with the market portfolio average returns, to quantify the capacity of them to identify sectors within the portfolio of securities market suitable to achieve extra profit compared with the market yield, In addition, compare the returns on the portfolio returns equity portfolio with high EVA to determine the superiority investment policy based on EVA from investment strategies including common accounting standards.

\section{Results}

To test the major hypotheses of the study and to achieve the comprehensive aim this paper consists of two parts. The first stage measured the returns achieved by the stock's portfolio with high EVA and analysed the returns contrary to those achieved by the stock market. The aim of this stage was to test the first hypothesis of the study. The revenues have been estimated daily and collected during the study period. Table 2 shows the results of this stage.

1- The stock's portfolio containing higher EVA got return during the observed period (-43.8\%), while the market index got $-76.3 \%$ in the same time. The average annual yield of the aggregate stock's portfolio with high EVA -14.38 percent whiles the average for the market portfolio was $(-21 \%)$. In spite of achieving a negative return for each of the portfolios, the performance of the stock's portfolio with high EVA was superior to the market performance during the study period.

2- The portfolio containing higher EVA reached $-24.5 \%$ within the first stage (first year), while the total return for the market index was $-43.1 \%$. The market portfolio had a negative return of $-82.1 \%$ and $-76.3 \%$ on the retention period of 24 and 36 months, respectively. Administration and sales of portfolio stocks with higher EVA value provided negative revenue of $-51.7 \%$ and $-43.8 \%$ for first and second year. So this result supports the stock portfolio with high EVA rather than the market portfolio.

3-The retained earnings for the period of 24 months (the period from 12th month to 36th month) for the market portfolio was $-28.5 \%$, and for the portfolio with higher EVA value the output was $-19.7 \%$.

The stock portfolio with high EVA, started achieving a positive accumulated profit during the third year of study. The percentage value is $+10 \%$, the market index achieved a positive return $+3.6 \%$ during the same period.

The results stated above indicates the market index achieved a negative revenue greater than the negative yield made by the stocks' portfolios with high EVA. According to that could be stated that portfolios taking into account the EVA values could bring some benefit for the stakeholders. In the case for the market trend to 
increase the yield for the equity portfolio, the EVA return is significantly lower than the market return. It can be explained by these results, the risk for shares with higher EVA plus market risk was lowered therefore, changes in the prices of these stocks and their returns are less than changes in the market index both in the case of a rise or a decline so the return (positive or negative) for the investigator of the shares with high e EVA is always less than the market return. The previously stated results are in contrary to the first hypothesis focused on the theory allegations which referred to the use of the EVA to design the investment policies conducive to extraordinary returns compared to market return. The second aim of our study was to compare the return achieved by investment policies based on the index earning multiplier and returns achieved by the investors' strategy icluding the EVA. The returns were measured by earnings for the stocks portfolio with the lowest earning's multiplier. Common returns on the market portfolio were then compared with the average return on equity portfolio with high EVA. Table 2 shows the results of this step:

1-The stocks portfolio with the lowest earnings' multiplier is the only one that has achieved a positive return on accumulated during the study period, and the percentage is $2.5 \%$, compared to a negative return of $-43.8 \%$, for the stocks' portfolio of with high EVA. The benchmark market return reached a negative of $-76.3 \%$ for the same period. This refers to be outperformed for the stock portfolio with the lowest multiple of earnings to the stock portfolio performance with high EVA and the average market return.

Table 2. Cumulative Holding Period Returns in \%. During the study period (stocks portfolio with a high EVA)

\begin{tabular}{|c|c|c|c|}
\hline Months & $\begin{array}{l}\text { Market index } \\
\text { CASE }\end{array}$ & $\begin{array}{c}\text { Portfolio of stocks with high } \\
\text { EVA }\end{array}$ & $\begin{array}{c}\text { Portfolio of stock with the lowest multiplier of } \\
\text { earning }\end{array}$ \\
\hline 1 & 2.5 & -0.8 & 4.2 \\
\hline 2 & 4.7 & -5.8 & 3.2 \\
\hline 3 & -4.5 & -7.3 & 0.6 \\
\hline 4 & -3.5 & -10.8 & -3.1 \\
\hline 5 & 15.5 & -11.9 & -5.3 \\
\hline 6 & -15.9 & -12.7 & -7.1 \\
\hline 7 & -25.3 & -18.3 & -14.1 \\
\hline 8 & -38.3 & -16.2 & -15.3 \\
\hline 9 & -41.2 & -16.7 & -8.2 \\
\hline 10 & -54.2 & -24.6 & -12.6 \\
\hline 11 & -48.8 & -23.0 & -11.8 \\
\hline 12 & -43.1 & -24.50 & 13.8 \\
\hline 13 & -42.5 & -27.7 & -11.6 \\
\hline 14 & -54.0 & -35.7 & -15.6 \\
\hline 15 & -61.9 & -40.2 & -21.7 \\
\hline 16 & -53.6 & -41.8 & -22.9 \\
\hline 17 & -51.7 & -34.5 & -18.4 \\
\hline 18 & -60.5 & -32.5 & -19.6 \\
\hline 19 & -71.6 & -34 & -19.9 \\
\hline 20 & -53.4 & -27.8 & -16.4 \\
\hline 21 & -67.3 & -35.2 & -13.8 \\
\hline 22 & -66.4 & -40.6 & -17.0 \\
\hline 23 & -73.5 & -52 & -19.8 \\
\hline 24 & -82.1 & -51.7 & -18 \\
\hline 25 & -86.9 & -62.4 & -17.7 \\
\hline 26 & -77.5 & -51.7 & -15.7 \\
\hline 27 & -78.9 & -44.2 & -13.9 \\
\hline 28 & -81.8 & -45.4 & -8.1 \\
\hline 29 & -83.1 & -46.6 & $-3,3$ \\
\hline 30 & -82.2 & -47.9 & -5.3 \\
\hline 31 & -84.1 & -47.3 & -0.1 \\
\hline 32 & -80.5 & -43.2 & -0.4 \\
\hline 33 & -84.1 & -43.7 & 0.0 \\
\hline 34 & -81.1 & -45.4 & 1.1 \\
\hline 35 & -79.5 & -48.1 & 1.5 \\
\hline 36 & -76.3 & -43.8 & 2.5 \\
\hline
\end{tabular}


2- The average return for the aggregate stocks portfolio per year stocks with the lowest earnings multiplier was $+1.15 \%$, while the stocks portfolio with higher EVA has a negative average accumulated annual return $-2.04 \%$, and the market portfolio reached the average of $-3.1 \%$. This findings correspond with the outperformed of the stocks portfolio with the lowest multiple compared with the rest of the portfolios.

3 - The aggregate return of the stocks' portfolio with the lowest revenues multiplier of the ratios was $-13.8 \%$, $-18 \%$ and $2.5 \%$, for a period of 12,24 and 36 months in a row, This was a better return than the return achieved for each one, the stock portfolio with high EVA and market portfolio over the same period.

4-The stock portfolio with the lowest earnings multiplier started to have a positive earnings return during the $3^{\text {rd }}$ year of the study. The value of this return was $14.7 \%$, while the revenue of the stocks portfolio with high EVA in the same period was $+11 \%$, while the market index reached a positive return about $1.6 \%$ during the same period. These results indicate that the portfolio based on the earning multiplier index overall provided higher performance of the market portfolio and stock portfolio with high EVA. Therefore, useless investment policies are based on EVA. Finally, the previous results are in the contrary of the $2^{\text {nd }}$ hypothesis of the research. The objective was to prove or reject the veracity of the assumption that the benefit of the investment strategies based on the scale of the EVA providing higher revenue than the strategty using the common tools based on accounting of given company. This also supports the results of a previous studies on the phenomenon of earning multiplier.

\section{Conclusion}

The EVA as a tool represents the concept of economic profits, which indicates that so as to achieve the value for shareholders; the company must manage the use of the available resources to achieve a return on invested capital greater than the cost of capital, whether owned or Borrowed.

Our research aimed to analyze and study these allegations and to bring an evidence of the usefulness of EVA, to interpret the stock returns. We tried to study and analysis the causality of stock return and EVA, addressed the extent of the benefit of the investment policy relying on the EVA in achieving normal returns compared with the average market and average returns provided by the investment strategy taking into account indicators based on accountancy. The study results showed that the EVA provided a clarification for the stock revenues and it is obvious that the investment strategy focused on the shares with a higher EVA doesn't have to cause the higher revenues compared with the market ones. These results agreed with the previous studies, which tested this relationship in the stock markets and the benefit of the investment policies adopted to measure the EVA compared with the normal (average) market return and normal return achieved by the policies adopted indicators of accounting. The results rejected the assumption of the benefit of using the investment strategies based on the EVA to achieve higher returns compared with strategies using common accounting indicators. The results showed that the investment policies based on the conventional accounting indicators were superior to those policies based on the EVA. In addition, the results showed the possibility of using the investment strategy including accounting indicators to achieving up normal returns compared with the average market return. Our results are consistent with the results of other authors. It could be said that our research represents next evidence which can be viewed in the light of the results of the previous studies, which refers to the lack of veracity of the theory claims relationship between the EVA, stock prices and stocks returns.

\section{References}

Basu, S. (1977). Investment performance of common stocks in relation to their price/ earning ratios: A test of the sufficient market hypothesis. Journal of Finance, 32(June), 663-682. http://dx.doi.org/10.1111/j.1540-6261. 1977.tb01979.x

Basu, S. (1983). The relationship between earning 'yields, market value and the return for NYSE stock: Further evidence. Journal of Financial Economics, 12, 129-156. http://dx.doi.org/10.1016/0304-405X(83)90031-4

Bernstein, R., \& Pigler, C. (1997). Quantitative Viewpoint: An Analysis of EVA. Merrill Lynch \& Co. Global Securities \& Economics Group. Quantitative \& Equity Research Department. (December).

Bernstein, R., Bayer, K., \& Pigler, C. (1998). Quantitative Viewpoint. An analysis of EVA-Part II. Merrill Lynch \& Co. Global Securities \& Economics Group. Quantitative \& Equity Research Department (February).

Biddle, G. C., Bowen, R. M., \& Wallace, J. S. (1999). Evidence on EVA. Journal of Applied Corporate Finance, (12), 69-79. http://dx.doi.org/10.1111/j.1745-6622.1999.tb00008.x

Fama, E., \& French, K. R. (1992). The cross - section of expected stock return. Journal of Finance, 47, 427-465. http://dx.doi.org/10.1111/j.1540-6261.1992.tb04398.x

Felltham, G., \& Ohlson, J. (1995). Valuation and clean surplus accounting for operating and financial activities, 
Contemporary Accounting Research (Spring, pp. 689-731). http://dx.doi.org/10.1111/j.1911-3846. 1995.tb00462.x

Feltham, G., \& Ohlson. J. (1996). Uncertainty resolution and the theory of depreciation measurement. Journal of Accounting Research, 34(Autumn), 209-234. http://dx.doi.org/10.2307/2491500

Fernandez, P. (2002). Three Residual Income Valuation methods and Discounted Cash Flow Valuation. Working Paper. Social Science Research Network. Retrieved from http://www.ssrn.com

Hamilton, R. (1777). An Introduction to Merchandize. Edinburgh Cited by Biddle, Bowen, and Wallace 1997.

Ittner, C. D., \& Larcker, D. F. (1998). Innovation in performance measurement: Trends and research implication. Journal of Management Accounting research, (10), 205-238.

Kothari, S. P. (2001). Capital market research in accounting. Journal of Accounting and Economics, 31(September), 105-231. http://dx.doi.org/10.1016/S0165-4101(01)00030-1

Kothari, S. P., \& Zimmerman, J. L. (1995). Price and return models. Journal of Accounting and Economics, 20, 155-192. http://dx.doi.org/10.1016/0165-4101(95)00399-4

Lakonishok, J., Shleifer, A., \& Vishny. R. W. (1994). Contrarian investment extrapolation and risk. Journal of Finance, 49, 1541-1578. http://dx.doi.org/10.1111/j.1540-6261.1994.tb04772.x

Lang, M. (1991). Time varying stock price response to earning induced by uncertainty about time series process of earning. Journal of Accounting research, (Autumn), 229-257. http://dx.doi.org/10.2307/2491048

\section{Copyrights}

Copyright for this article is retained by the author(s), with first publication rights granted to the journal.

This is an open-access article distributed under the terms and conditions of the Creative Commons Attribution license (http://creativecommons.org/licenses/by/3.0/). 